\title{
DETERMINANTS OF FINANCIAL CAPABILITY: EVIDENCE FROM A TRANSITION COUNTRY
}

\author{
Gentjan Çera, Bekim Poleshi, Khurram Ajaz, Khan, Arjan Shumeli, \\ Oksana Kojku
}

\begin{abstract}
Among scholars, academicians and policymakers there is a constant concern on how to improve financial literacy and capability of individuals. In this regard, this study seeks to investigate the effect of financial literacy along with demographic factors on individuals' financial capability. This research is administrated on an individual-level data collection through a survey. This paper uses hierarchical multiple regression with two steps in a dataset of 200 respondents from a transition country, Albania. Results demonstrated that financial capability is affected by financial knowledge and financial behaviour. In addition, individuals that were single, unemployed and young negatively influenced financial capabilities. However, having higher incomes positively impacted financial capability. These findings are consistent with the literature in the field of financial literacy. Financial attitude and gender did not show any significant effect on financial capability. This paper contributes to enriching the literature of the field by offering evidence on how financial literacy and demographic factors drive individuals' financial capability. In addition, this current study provides useful insights for academicians, educational institutions managers, and public-policy advocates responsible for designing curricula and strategies to increase the level of individuals' financial capability.
\end{abstract}

Keywords: financial capability, financial attitude, financial knowledge, financial behaviour, hierarchical linear regression, Albania

\section{INTRODUCTION}

We are all witnesses of the rapid development that the global economy is facing from the last decades. Banking products and financial markets are becoming more and more complex. It is almost impossible to be indifferent to this situation because, in one way or another, we all face certain financial situations in our daily lives. In that sense, it is very important for economic agents to be on the same line of development as the economy and its branches, especially for individuals. In today's economic reality there are some problems that need to be resolved as soon as possible, problems that are common in almost all the countries.

Albania is a transition country and of course, its economic agents are heavily affected by these kinds of problems - low levels of financial inclusion and access to financial products, poor planning and decision-making related to savings or investments, bad management of incomes and spending, etc. It is believed that most of these kinds of problems are a derivative of low financial capability and its causative factors. This situation has big consequences on individuals and since an individual is considered to be the basic cell of a society, this will negatively impact the economy as a whole. Based on what most of the researchers conclude, nowadays the governments in different countries pursue policies geared to increasing financial literacy and financial capability of individuals - providing a favourable environment for people to understand the complexities of their finance, take optimal financial decisions and setting other financial goals wisely. The promotion of financial capability at individuals is being always more significant in recent years (Loke, Choi \& Libby, 2015). The policy-makers consider it as a challenge that needs to be won and recently they are making strong calls to increase individuals' 
financial capability (Batty, Collins \& Odders-White, 2015). In a transition country like Albania, it is essential for economic agents to have the appropriate level of financial literacy and financial capability to be more efficient in economic decision-making and to have more access to financial products. To do so, people must develop a certain level of financial attitude, financial knowledge and financial behaviour (Hira, 2012).

This paper aims to indicate the factors that drive individuals' financial capability and to examine the relationship that exists between them. The study provides a statistical analysis based on a survey where 200 random individuals responded to some particular statements designed to measure the level of financial capability, knowledge, attitude, and behaviour. The local literature on this issue is not very rich, so this topic may be something of interest to researchers, academicians, policy-makers or other people related to this field of study as it aims to shed light on an issue about which there exist clear information gaps.

In this regard, several research questions can be raised and this paper aims to provide answers: does the level of financial attitude, knowledge, and behaviour of individuals affect their financial capability? Regarding demographic factors, how do they relate to individuals' financial capability? How does this problem stand in the researchers' point of view? What can be done to improve the overall level of financial capability at individuals?

\section{LITERATURE REVIEW}

There is a large number of researchers who are focused on the concept of financial capability, its importance to the individuals and the main influencing factors. In fact, the literature of the field suggests that there is a variety of factors that can affect the level of individuals' financial capability. Different authors emphasize the effect of financial literacy on individuals' financial capability, as well as the effect of some demographic factors.

In theory, financial literacy is heavily linked with financial capability, but do we understand financial literacy? This is a concept that doesn't have a single definition. As Vieira, Caroline and Potrich (2019) explained, the term 'financial literacy' has often been used as a synonym for financial education or financial knowledge, but in fact it is not the same thing. Huston (2010) gives two dimensions for financial literacy: understanding, which refers to the level of personal knowledge for financial terms and concepts, and use, which refers to the application or the management of these knowledge. Financial experts often use this term to describe a group of knowledge and skills which are necessary to effectively manage money (Remund, 2010). Atkinson and Messy (2012) agreed on a conceptual framework related to the concept of financial literacy - they see it as a function of financial knowledge, financial attitude, and financial behaviour. This is a widely used definition and, the same is the reason for using it in the current study.

What about the financial capability? As a matter of fact, in theory, financial capability is considered as a relatively new concept emerged in the recent years. Jian, Chen and Chen (2014) define financial capability as the application of financial knowledge and as they explain, individuals' financial capability favours such financial behaviours that influence the enhancement of overall financial well-being. Bumcrot et al. (2013) state that financial capability is measured in terms of how well people make ends meet, plan ahead, choose and manage financial products, and possess the skills and knowledge to make financial decisions. Financial capability is introduced to broaden the concept of financial literacy (Kempson, Perotti \& Scott, 2013). Researchers conceptualized financial capability not only as knowledge, but they say that the term 'financial capability' includes the individuals' ability to use this knowledge in their daily lives. 
In the light of the literature review, the following variables are taken into consideration financial literacy (attitude, knowledge, and behaviour) and selected demographic factors (age, gender, marital status, occupation and the level of income). The above discussion supports to examine the relationship between financial capability and selected financial and demographic factors. Hence, the objective of the study is to develop a conceptual framework, set the hypothesis and support or reject them through the statistical evidence.

Referring to the theoretical model considered in this paper, financial attitude is one of the threebuilding pillars of financial literacy (along with financial knowledge and financial behaviour). Rai, Dua and Yadav (2019) have defined financial attitude as the tendency of individuals towards financial matters or as a way of approaching financial issues. Other researchers of the field define financial attitude as the reaction of the individuals towards money-related issues like investment, saving, setting financial goals, etc. There are also some researchers that have a different point of view for the definition of individuals' financial attitudes. For example, Woodyard and Robb (2012) conceptualized the financial attitude as a subcategory of financial perception. They suggested that financial attitude includes subjective financial knowledge that is related to social factors, financial well-being and the importance of setting financial goals for the future.

The theory also discussed whether financial attitude affects the financial capability of individuals. Shim, Serido, Bosch and Tang (2013) reinforce this approach in their study as they approve this relationship arguing that financial attitude can influence financial capability. Based on the findings of Batty, Collins and Odders-White (2015), the study indicates that improved financial attitudes and behaviours are known to boost the financial capability of individuals, a fact that supports a possible positive relationship between financial attitude and financial capability. Although, an indirect relationship between these concepts were presented by some researchers. Referring to Potrich, Vieira and Mendes-Da-Silva (2016), financial attitude precedes financial behaviour and referring to Homer and Kahle (1988), financial attitude influences financial behaviour. The researchers argue that there is a direct and positive relationship between financial attitude and financial behaviour. Since the literature of the field suggests that financial behaviour influences financial capability, we can say that financial attitude may impact financial capability. In fact, a direct relationship between financial attitude and financial capability is yet to be proven, hence this study will try to examine the relationship. Regarding the above discussion, a hypothesis can be framed as:

Hypothesis 1 (H1): Financial attitude positively affects financial capability

In theory, there are several definitions related to individuals' financial knowledge. In simple words, knowledge can be defined as what we know, it can also be defined as a group of knowledge limited to a certain field, in this case, the economic field - but these are general definitions. Faulcon Bowen (2002) defines financial knowledge as an understanding of key financial terms and concepts. Referred to this author, the concept of financial knowledge of individuals includes knowledge related to banking and savings, insurance, use of credit card, taxes and investing. While Rothwell, Khan and Cherney (2016) state financial knowledge as an individual's understanding of microeconomics, macroeconomics and personal finance. Also, these authors consider financial knowledge to be an internal capability of individuals. On the other hand, Delavande, Rohwedder and Willis (2009) consider financial knowledge to be a particular type of human capital related to the ability to manage incomes, expenditures and savings in a safe way.

Financial knowledge as a concept has been strongly linked to financial capability by the researchers of the field. There are a lot of researchers who have done numerous researches related to this issue as it is considered a very important one. As we mentioned above, financial 
knowledge means learning new concepts related to the field of economy or finance. But learning new financial concepts, based on Batty, Collins and Odders-White (2015) findings, affects individuals' financial capability levels. These researchers say in their study that the process of increasing the level of overall financial knowledge is heavily associated with improved financial attitudes and financial behaviours. Since financial knowledge, financial attitude and financial behaviour are considered as building pillars of financial literacy and financial literacy itself is proven to have a positive impact on individuals' financial capability, it's fair to say that higher levels of financial knowledge derive higher levels of financial capability. Also, we can conclude that by increasing our financial knowledge, we create a good base of financial capability in the long run. Based on the above discussion, the following hypothesis is formulated:

Hypothesis 2 (H2): An increased level of financial knowledge results in an increased level of financial capability.

Behavioural finance is a relatively new field of economics. The way individuals behave concerning financial issues has taken increasing attention from the researchers in the last decade. Financial behaviour is a complex term that includes all the financial activities done by economic agents (Mudzingiri, Muteba Mwamba \& Keyser, 2018). Similarly, Bhushan (2014) also defined financial behaviour as any behaviour related to financial decision-making and money management. Rai et al. (2019) stated in their study such financial behaviours like financial planning, saving, budgeting, investing, debt payment, etc.

The number of studies has legitimated a significant relationship between financial behaviour and the financial capability of individuals. In theory, higher levels of financial behaviours are associated with higher financial capability. Actually, individuals' financial behaviour is considered as a very important area to be studied from the researchers' point of view in the recent years. For example, in their study, Potocki and Cierpiał-Wolan (2018) consider financial behaviour as an essential factor in determining the individuals' financial capability. In the same line are Mitchell and Lusardi (2011), whose findings show that individuals' financial capability can be measured through financial behaviour. Recent studies consider financial behaviour to be one of the most important factors affecting financial capability. Jian et al. (2014) are in the same logic line as they highlight the fact that financial behaviour has a big impact on the financial capability of individuals. Thus:

Hypothesis 3 (H3): There is a positive relationship between financial behaviour and financial capability.

The demographic factors are seen with interest from researchers about how they are related to financial capability. In fact, several variables have been shown as significant predictors of financial literacy and financial capability. In literature, there are mentioned demographic factors like age, ethnicity, gender, education level, income level, marital status, occupation, region, wealth, residential area, housing, the number of children, health, etc. In this paper we are taking into consideration age, gender, marital status, education and occupation and we will try to examine the relationship that they have with financial capability.

Based on a study that Lusardi, Mitchell and Curto (2010) have made, there are significant differences in financial literacy level based on demographic variables such as gender, age or income. Since financial literacy was told to have a big impact on financial capability, logically we assume that these demographic factors have a similar effect on financial capability too. Regarding incomes, Atkinson et al. (2007) in their paper show that consumers with different incomes have different concepts for financial capability, concluding that those with higher incomes tend to have higher levels of financial capability and those with lower incomes tend to be financially incapable. Regarding this issue, Taylor (2009) also observed the impact of some 
demographic factors on financial capability and concluded that those who are young (aged less than 35), single and/or unemployed, show lower levels of financial capability. Bumcrot et al. (2013) are in the same line as they find in their study that the young and those with low education are very likely to have low financial capability. Therefore:

Hypothesis 4 (H4): Demographic factors (income, H4a; being not single, H4b; being male, H4c, employed, H4d) positively influence individuals' financial capability.

The above discussion is based on what the researchers of the field have concluded. Considering their findings, the current study raised four different hypothesis that may be accepted or rejected on the basis of the framed conceptual framework (see Figure 1).

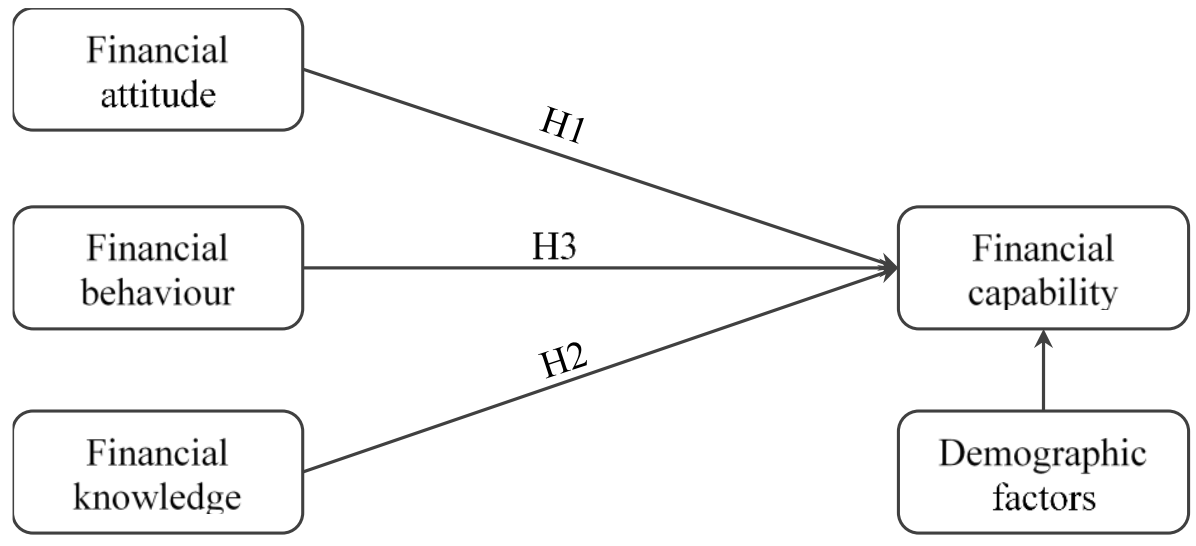

Fig. 1 - Theoretical model. Source: own research

\section{METHOD AND PROCEDURES}

\subsection{Variable measurement}

As with previous researches, financial attitudes, knowledge, behaviour and capability were measured as self-reported scale (Allgood \& Walstad, 2016; Gutter, Copur, \& Garrison, 2016; Shih \& Ke, 2014). Several indicators per each factor were found in the literature. Each indicator was formulated as a statement with five possible answers ([1] Strongly disagree, [2] Disagree, [3] Neither disagree, nor agree, [4] Agree, [5] strongly agree), making it a Likert type scale. Our variables were created as the mean of these indicators.

The dependent variable in the current research is financial capability. It was measured by five indicators, which are: I can arrange at least 1000\$ (AL: 70000 ALL) in an unexpected needs arose within the next month; I have enough funds to survive for three months without regular earnings; I often use electronic payment mode for paying bills through (credit card, debit card, online banking, mobile banking etc.); I have too much debt right now; I am good at dealing with day-to-day financial matters, such as checking accounts, credit and debit cards and tracking expenses. This scale was proposed by a prior study (Robb \& Woodyard, 2011) and the National Financial Capability Study in 2012 covering the United States of America.

Influenced by several prior scholars and experts in the field of financial literacy (Atkinson \& Messy, 2011, 2012; Garber \& Koyama, 2017; Potrich, Vieira \& Kirch, 2015), financial attitude was measured by eight statements, which are: It is important to set goals for the future; I tend to live for today and let tomorrow take care of itself; After making a decision about money, I tend to worry too much about my decision; I find it more satisfying to spend money than save it for the long term; Money is there to be spent; I pay my bills on time; I keep a close personal watch on my financial affairs; I am prepared to risk some of my own money when saving or making an investment. 
There are two types of measuring financial knowledge: objectively and subjectively (Serido, Shim \& Tang, 2013). In this paper, the subjective type was used. Hence, financial knowledge was measured by eight items: Investing in different assets reduce risk; It is less likely that you will lose all of your money if you save them in more than one place; I understand the cost of buying on credit; I am pretty good at calculation like profit and loss, percentage etc.; An investment with a high return is likely to be high risky; High inflation mean that the cost of living is increasing rapidly; If price goes up rapidly, the money people have in saving accounts could lose much of its value; Electronic fund transfers are riskless (credit card, debit card, online banking etc.). This scale was developed as a combination of several prior studies (Çera \& Tuzi, 2019; Faulcon Bowen, 2002; Lusardi \& Mitchelli, 2007; Robb \& Woodyard, 2011).

In accordance with prior researches (Joo \& Grable, 2004; Potrich et al., 2016), six indicators were used to measure financial behaviour: I take notes and control my personal expenses (e.g., expense and revenue spreadsheet); I establish financial targets for the long term that influence the managing of my expenses; I follow a weekly or monthly plan for expenses; I compare prices when buying something; I analyse my financial situation before a big purchase; I have plans to achieve my financial goals (retirements, savings, investments etc.).

Table 1 informs about the descriptive statistics of our composed variables: financial attitude, financial knowledge, financial behaviour, and financial capability. As it can be seen, the mean of financial attitude was 3.477, and its values ranges from 1 to the maximum possible number of Likert scale (5). This ranges of values was reported even in case of financial behaviour with a mean of 3.743. Financial knowledge reflected a mean of 3.494, minimum of 1.250 and a maximum of 4.875 . The minimum, mean and maximum values of financial capability were 1 , 2.996 and 4.750 .

Tab. 1 - Descriptive statistics for the composed variables. Source: own research

\begin{tabular}{|llcccc|}
\hline Variable & Code & Number of items & Min & Mean & Max \\
\hline Financial attitude & fin_att & 8 & 1.000 & 3.477 & 5.000 \\
Financial knowledge & fin_knw & 8 & 1.250 & 3.494 & 4.875 \\
Financial behaviour & fin_beh & 6 & 1.000 & 3.743 & 5.000 \\
Financial capability & fin_cap & 5 & 1.000 & 2.996 & 4.750 \\
\hline
\end{tabular}

\subsection{Method}

Hierarchical multiple regression with two steps was performed in way to test the effect of financial attitude, knowledge, and behaviour along with demographic variables on financial capability. This method was used because it tests the significance of inclusion into the analysis sets of variables in the forms of blocks. In the current research, the first block of variables consists of demographic ones such as age, gender, unemployed, material status (single) and income. In the second step (block of variables), financial literacy variables were included. By doing so, this type of regression can inform what is the contribution of each set of variables to the explanation of the dependent variable (Pallant, 2016). The dependent variable was financial capability. Its mathematical form can be written:

$$
\begin{aligned}
\text { fin_cap }=\overbrace{\beta_{0}+\begin{array}{l}
\beta_{1} \text { age }+\beta_{2} \text { male }+\beta_{3} \text { singel }+\beta_{4} \text { unemployed }+\beta_{5} \text { income } \\
+\underbrace{\beta_{6} f i n \_a t t+\beta_{7} f i n \_k n w+\beta_{8} f i n \_b e h}_{\text {second step }}
\end{array}}^{\text {first step }}
\end{aligned}
$$

All analyses were done using computer statistical software SPSS version 23 (Meyers, Gamst \& Guarion, 2013). 


\subsection{Sample}

To test the proposed hypotheses in the theoretical model (see Figure 1), initially a questionnaire in the Albanian language was developed based on literature review. The questionnaire contained two main sections: indicators for four constructs of our theoretical model, along with the demographic characteristics.

The target population consists of adult individuals aged from 18 to 70 living in Albania. The stratified sample technique was applied. Thus, the sample size was designed based on the distribution of the Albanian population in terms of age, gender and region. The collection phase of the data took place on June 2019. The subjects were approached physically, so the questionnaire was filled in face-to-face. About 30 respondents were removed from the sample because it was noticed the same answer for several statements when logically it should not be so. The final sample consists of 200 valid respondents.

Table 2 illustrates the sample profile in terms of demographic variables. The majority of respondents were females (59\%), single (55.5\%) and employed (66.5\%). The average age respondents were 29.6 years old (the youngest was 18 years old, whereas the oldest was 70 years old). The sample distributions according to income levels were: from the lowest category were $25 \%$, from the second level were $42.5 \%$ and the rest were from the fourth and highest levels of income.

Tab. 2 - Sample profile. Source: own research

\begin{tabular}{|llcc|}
\hline Category & Sub-category & $\mathrm{N}$ & Percent \\
\hline Gender & Female & 118 & 59 \\
& Male & 82 & 41 \\
\cline { 2 - 4 } Material status & Single & 111 & 55.5 \\
\multirow{5}{*}{ Employment } & Others & 89 & 44.5 \\
\cline { 2 - 4 } & Unemployed & 67 & 33.5 \\
Income & Employed & 133 & 66.5 \\
\cline { 2 - 4 } & Less than 26 000 ALL & 50 & 25 \\
& $26000-50000$ ALL & 85 & 42.5 \\
Total valid & $50000-100000$ ALL & 45 & 22.5 \\
& More than 100 000 ALL & 20 & 10 \\
\cline { 2 - 5 } & & 200 & 100 \\
\hline
\end{tabular}

Note: Exchange rate on $5^{\text {th }}$ October 2019: 1 USD $=111.62$ ALL, 1 EUR $=122.56$ ALL.

\section{FINDINGS AND DISCUSSION}

\subsection{Empirical findings}

As mentioned in the previous section, hierarchical linear regression was applied to test the proposed hypotheses. Tables 3 and 4 report basics statistics of the models and analysis of variance. Model 1 includes five independent variables (income, male, single, unemployed, and age), which explained $26.9 \%$ of the financial capability's variance, $F(5,194)=15.623, p<$ .001. After entry of the new variables (fin_knw, fin_att, and fin_beh) at the second step of the model, the total variance explained by the model as a whole was $41.2 \%, F(8,191)=16.715, p$ $<.001$. The three added variables explained an additional $12.5 \%$ of the variance in financial capability, after controlling for demographic variables, $R$ squared change $=.125, F$ change (3, $191)=13.502, p<.001$. This considerable increase in the explained variance in the dependent variable demonstrates the importance of financial literacy in explaining financial capability. 
Tab. 3 - Model summary. Source: own research

\begin{tabular}{|c|c|c|c|c|c|c|c|c|c|}
\hline \multirow[b]{2}{*}{ Model } & \multirow[b]{2}{*}{$\mathrm{R}$} & \multirow[b]{2}{*}{$\begin{array}{c}\mathrm{R} \\
\text { Square } \\
\end{array}$} & \multirow[b]{2}{*}{$\begin{array}{l}\text { Adjusted } \\
\text { R Square }\end{array}$} & \multirow[b]{2}{*}{$\begin{array}{l}\text { Std. Error of } \\
\text { the Estimate }\end{array}$} & \multicolumn{5}{|c|}{ Change Statistics } \\
\hline & & & & & $\begin{array}{l}\text { R Square } \\
\text { Change }\end{array}$ & F Change & df1 & df2 & $\begin{array}{c}\text { Sig. F } \\
\text { Change }\end{array}$ \\
\hline 1 & $.536^{\mathrm{a}}$ & .287 & .269 & .66389 & .287 & 15.623 & 5 & 194 & .000 \\
\hline 2 & $.642^{b}$ & .412 & .387 & .60774 & .125 & 13.502 & 3 & 191 & .000 \\
\hline
\end{tabular}

a. Predictors: Constant, income, male, single, unemployed, age

b. Predictors: Constant, income, male, single, unemployed, age, fin_knw, fin_att, fin_beh

Tab. 4 - Analysis of variance. Source: own research

\begin{tabular}{|ll|c|c|c|c|c|}
\hline \multicolumn{2}{|l|}{ Model } & Sum of Squares & df & Mean Square & F & Sig. \\
\hline 1 & Regression & 34.429 & 5 & 6.886 & 15.623 & $.000^{\mathrm{b}}$ \\
& Residual & 85.506 & 194 & .441 & & \\
& Total & 119.935 & 199 & & & \\
\hline 2 & Regression & 49.389 & 8 & 6.174 & 16.715 & $.000^{\mathrm{c}}$ \\
& Residual & 70.545 & 191 & .369 & & \\
& Total & 119.935 & 199 & & & \\
\hline
\end{tabular}

Note: Dependent variable: fin_cap; b. Predictors: constant, income, male, single, unemployed, age; c. Predictors: constant, income, male, single, unemployed, age, fin_knw, fin_att, fin_beh

Table 5 summarises the results of the effect of each variable on financial capability. Hence, for the first block of variables, it was found that three out of five variables were statistically significant in predicting individuals' financial capability. The significant effects originated from age, being unemployed, and level of income. As the age of individuals increased, the financial capability level of individuals diminished, $\beta=-.185, t=2.140, p<.05$. Being unemployed reduced the level of an individual's financial capability, $\beta=-.240, t=3.197, p<$ .01 . On the other hand, as the individuals' income increased, the higher was the level of financial capability, $\beta=.370, t=5.257, p<.001$. The effect of material status on financial capability was found to be at the edge of acceptance as an important variable, $\beta=-.141, t=$ $1.648, p=.101$. It was believed that the inclusion of other variables could transform this variable into a significant one. Gender was not an important predictor of the individual's financial capability, $\beta=-.023, t=.355, p>.10$.

In the second sequence of the regression were added new variables covering financial literacy (financial attitude, financial knowledge, and financial behaviour). Regression revealed that financial knowledge positively influenced individuals' financial capability, $\beta=.165, t=2.563$, $p=.011$, supporting $\mathrm{H} 2$. A positive relationship was reported even between financial behaviour and financial capability, $\beta=.282, t=4.221, p<.001$, supporting $\mathrm{H} 3$. The data failed to support the positive relationship between financial attitude and financial capability, $\beta=-.034, t=.547$, $p>.10$, rejecting $\mathrm{H} 1$.

Along with the added variables into the second step of the regression, the effect of demographic factors on financial capability was assessed. As it was expected from the first sequence of the regression, being single statistically influenced individuals' financial capability, $\beta=-.137, t=$ $1.731, p<.10$. So, those that were single reflected lower values in financial capability, as compared to the other material statuses. Referring to the other demographic factors, almost similar results were noticed as in the first step of the model. Hence, financial capability was negatively influenced by (besides being single) being unemployed $(\beta=-.241, t=3.469, p<$ $.001)$ when compared to those employed, and young individuals $(\beta=-.231, t=2.859, p<.01)$. The level of income positively impacted financial capability, $\beta=.279, t=4.226, p<.001$. Thus, excluding material status, demographic variables affect financial capability, supporting H4. 
Tab. 5 - Results of the regression. Source: own research

\begin{tabular}{|c|c|c|c|c|c|c|c|c|}
\hline \multirow{2}{*}{\multicolumn{2}{|c|}{ Model }} & \multicolumn{2}{|c|}{$\begin{array}{l}\text { Unstandardized } \\
\text { coefficients }\end{array}$} & \multirow{2}{*}{$\begin{array}{c}\begin{array}{c}\text { Standardized } \\
\text { coefficients }\end{array} \\
\text { Beta }\end{array}$} & \multirow[b]{2}{*}{$\mathrm{t}$} & \multirow[b]{2}{*}{ Sig. } & \multicolumn{2}{|c|}{$\begin{array}{l}\text { Collinearity } \\
\text { statistics }\end{array}$} \\
\hline & & $\mathrm{B}$ & Std. Error & & & & Tolerance & VIF \\
\hline \multirow[t]{6}{*}{1} & constant & 2.968 & .276 & & 10.739 & .000 & & \\
\hline & unemployed & -.393 & .123 & -.240 & -3.197 & .002 & .653 & 1.531 \\
\hline & single & -.220 & .133 & -.141 & -1.648 & .101 & .501 & 1.996 \\
\hline & male & -.036 & .101 & -.023 & -.355 & .723 & .893 & 1.119 \\
\hline & age & -.013 & .006 & -.185 & -2.140 & .034 & .493 & 2.028 \\
\hline & income & .312 & .059 & .370 & 5.257 & .000 & .742 & 1.347 \\
\hline \multirow[t]{9}{*}{2} & constant & 1.392 & .433 & & 3.218 & .002 & & \\
\hline & unemployed & -.395 & .114 & -.241 & -3.469 & .001 & .638 & 1.568 \\
\hline & single & -.214 & .123 & -.137 & -1.731 & .085 & .491 & 2.037 \\
\hline & male & -.012 & .093 & -.008 & -.132 & .895 & .873 & 1.145 \\
\hline & age & -.016 & .006 & -.231 & -2.859 & .005 & .470 & 2.127 \\
\hline & income & .235 & .056 & .279 & 4.226 & .000 & .706 & 1.416 \\
\hline & fin_att & -.048 & .087 & -.034 & -.547 & .585 & .796 & 1.256 \\
\hline & fin_knw & .225 & .088 & .165 & 2.563 & .011 & .741 & 1.350 \\
\hline & fin_beh & .322 & .076 & .282 & 4.221 & .000 & 691 & 1.448 \\
\hline
\end{tabular}

Note: Dependent variable: fin_cap; unemployed ( $1=$ yes, $0=$ no); single $(1=$ single, $0=$ otherwise), male $(1=$ male, $0=$ otherwise); age (scale variable), income (categorical variable).

Concerning the assumption dealing with multicollinearity, the hierarchical multiple regression evaluates two statistics: tolerance and variance inflation factor (VIF). Sufficient evidence was found supporting its absence in both steps of the model since among all VIF values, was not found any value above the conservative threshold (value of 3) (see Table 5). Alternatively, the tolerance values for each variable were reported higher than the minimum criteria of .10 (Pallant, 2016). These findings emphasized that the multicollinearity assumption was not violated.

\subsection{Discussion}

The current paper has shown insight results regarding the links between components of financial literacy (financial knowledge, attitude, and behaviour) and individuals' financial capability. The data revealed that financial capability was significantly related to financial knowledge and behaviour. Moreover, demographic factors were found to be important in predicting individuals' financial capability.

Financial capability can be predicted by financial knowledge. Indeed, results showed that the relationship between them was positive and significant. This means that as the level of financial knowledge increases, the higher the individual's financial capability. Prior studies have demonstrated similar results (Chowa, Ansong \& Despard, 2014; Potocki \& Cierpiał-Wolan, 2019; Rothwell, Khan \& Cherney, 2016; Serido et al., 2013; Xiao, Chen \& Chen, 2014). The current paper found evidence supporting the positive influence of financial behaviour on individuals' financial capability. Similar to the case of financial knowledge, an increase in financial behaviour leads to the improvement of financial capability. This finding goes in line with previous research conducted in this field (Potocki \& Cierpiał-Wolan, 2019; Serido et al., 2013; Vlaev \& Elliott, 2017). Demographic factors significantly influence on individuals' financial capability. Hence, being single, unemployed and young negatively affect financial capability. These findings are consistent with prior research (Friedline \& West, 2016; Potocki \& Cierpiał-Wolan, 2019; Taylor, 2009; Xiao, Chen \& Sun, 2015). On the other hand, having high income could lead to better levels of financial capability, which is consistent with prior studies (Atkinson et al., 2007; Jian et al., 2014; Xiao \& O’Neill, 2016). 


\section{CONCLUSION}

This paper was aimed to find the determinants of the financial capability of adult individuals living in a transition country. A burgeoning interest is growing on financial literacy and capability, focusing on their determinants and consequences (Feng, Lu, Song, \& Ma, 2019; Lusardi \& Mitchell, 2014; Luukkanen \& Uusitalo, 2019; Potocki \& Cierpiał-Wolan, 2019). In this context, the current study offers evidence regarding important factors that influence individuals' financial capability.

This study provides useful insights which in turn can be divided into theoretical and academic contributions. The modification of the conceptual framework is one of the contributions. Even though financial capability was expected to be determined by financial literacy (financial attitude, knowledge, and behaviour) along with demographic variables, the financial attitude was found to be an insignificant factor. This finding contradicts previous studies (Luukkanen \& Uusitalo, 2019; Sherraden \& Ansong, 2016). Due to this fact, additional efforts should be made to distinguish the meaning of financial attitude and financial capability. Albanians are introduced with financial means relatively recently. Albania is a post-communist country yet under transition from the previous system to a free-market one. In addition to this, gender did not influence financial capability, while prior research has demonstrated its importance in this regard (Çera \& Tuzi, 2019; Chen \& Volpe, 2002; Feng et al., 2019; Potrich, Vieira \& Kirch, 2018). On the other hand, the paper's findings are useful for policymakers and managers of educational institutions in Albania. They are strongly encouraged to adopt or design new curricula, policies, and strategies in a way to increase the level of financial capability. Taking these actions can be motivated by the results of this study, which stressed out that the level of financial capability can be improved by increasing the level of financial knowledge and behaviour. Since, compared to old individuals, young adults reflected the lower level of financial capability, curricula in higher education institutions should pay more attention to financial literacy, especially to the components related to financial knowledge and behaviour.

The results of this study are useful for designing policies with the main purpose of enhancing the knowledge and skills of young people living in Tirana, on the management of personal finances and to recommend a mechanism that should be used to ensure a satisfactory level of financial literacy. Study results are useful to policymakers since differences in financial literacy in terms of gender among young people were identified. Therefore, policymakers should pay attention to differences in gender when they design the financial education policy.

Even though the aim of the paper was fulfilled, yet there are some limitations. In terms of generalization of its finding, although the statistical method revealed significant relationships in the context of Albania, yet again they cannot transfer to the other countries. This limitation can be overcome with further research by replicating it to the other countries. From the methodological point of view, more rigor methods can be used to test the proposed hypotheses in this study. Further research is encouraged to apply other methods such as nonparametric ones or structural equation modelling.

\section{Acknowledgment}

This paper was supported by the Internal Grant Agency of Faculty of Management and Economics, Tomas Bata University, no. IGA/FaME/2019/002: The role of institutional environment in fostering entrepreneurship. 


\section{References}

Allgood, S., \& Walstad, W. B. (2016). The effects of perceived and actual financial literacy on financial behaviors. Economic Inquiry, 54(1), 675-697. doi: 10.1111/ecin.12255

Atkinson, A., McKay, S., Collard, S., \& Kempson, E. (2007). Levels of Financial Capability in the UK. Public Money and Management, 27(1), 29-36. doi: 10.1111/j.14679302.2007.00552.x

Atkinson, A., \& Messy, F. A. (2011). Assessing financial literacy in 12 countries: an OECD/INFE international pilot exercise. Paris, France: OECD.

Atkinson, A., \& Messy, F. A. (2012). Measuring Financial Literacy: Results of the OECD / International Network on Financial Education (INFE) Pilot Study. Paris, France: OECD

Batty, M., Collins, J. M., \& Odders-White, E. (2015). Experimental evidence on the effects of financial education on elementary school students' knowledge, behavior, and attitudes. Journal of Consumer Affairs, 49(1), 69-96. doi: 10.1111/joca.12058

Bhushan, P., \& Medury, Y. (2014). An Empirical Analysis of Inter Linkages Between Financial Attitudes, Financial Behaviour and Financial Knowledge of Salaried Individuals. Indian Journal of Commerce \& Management Studies, 5(3), 58-64. Retrieved from https://search-proquest-com.proxy.k.utb.cz/docview/1561350615?accountid=15518

Bumcrot, C. B., Lin, J., \& Lusardi, A. (2011). The Geography of Financial Literacy. Advancing Education in Quantitative Literacy, 6(2), 1-26. doi: 10.5038/1936-4660.6.2.2

Çera, G., \& Tuzi, B. (2019). Does gender matter in financial literacy? A case study of young people in Tirana. Scientific Papers of the University of Pardubice, Series D, 45(1), 516. Retrieved from https://dk.upce.cz/handle/10195/72241

Chen, H., \& Volpe, R. P. (2002). Gender differences in personal financial literacy among college students. Financial Services Review, 11, 289-307. doi: 10.5897/AJBM10.1267

Chowa, G., Ansong, D., \& Despard, M. R. (2014). Financial Capabilities: Multilevel Modeling of the Impact of Internal and External Capabilities of Rural Households. Social Work Research, 38(1), 19-35. doi: 10.1093/swr/svu002

Delavande, A., Rohwedder, S., \& Willis, R. J. (2009). Preparation for Retirement, Financial Literacy and Cognitive Resources. Michigan Retirement Research Center Research Paper, No. 2008-190, 1-45. doi: 10.2139/ssrn.1337655

Faulcon Bowen, C. (2002). Financial Knowledge Of Teens And Their Parents. Financial Counseling and Planning, 13(2), 93-101. Retrieved from https://search-proquestcom.proxy.k.utb.cz/docview/1355863175?accountid=15518

Feng, X., Lu, B., Song, X., \& Ma, S. (2019). Financial literacy and household finances: A Bayesian two-part latent variable modeling approach. Journal of Empirical Finance, 51, 119-137. doi: 10.1016/j.jempfin.2019.02.002

Friedline, T., \& West, S. (2016). Financial Education is not Enough: Millennials May Need Financial Capability to Demonstrate Healthier Financial Behaviors. Journal of Family and Economic Issues, 37(4), 649-671. doi: 10.1007/s10834-015-9475-y

Garber, G., \& Koyama, S. M. (2017). Policy-effective Financial Knowledge and Attitude Factors. Central Bank of Brazil Working Papers, No. 430, 1-47. Retrieved from https://www.bcb.gov.br/pec/wps/ingl/wps430.pdf

Gutter, M. S., Copur, Z., \& Garrison, S. (2016). Do the financial behaviours of college students vary by their state's financial education policies? In C. Aprea, E. Wuttke, K. Breuer, N. 
K. Koh, P. Davies, B. Greimel-Fuhrmann \& J. S. Lopus (Eds.), International Handbook of Financial Literacy. Singapore: Springer. doi: 10.1007/978-981-10-0360-8_15

Hira, T. K. (2012). Promoting sustainable financial behaviour: implications for education and research. International Journal of Consumer Studies, 36(5), 502-507. doi: 10.1111/j.1470-6431.2012.01115.x

Homer, P. M., \& Kahle, L. R. (1988). Personality Processes and Individual Differences: A Structural Equation Test of the Value-Attitude-Behavior Hierarchy. Journal of Personality and Social Psychology, 54(4), 638-646. Retrieved from https://psycnet.apa.org/record/1988-21933-001

Huston, S. J. (2010). Measuring Financial Literacy. Journal of Consumer Affairs, 44(2), 296316. doi: 10.1111/j.1745-6606.2010.01170.x

Jian, J., Chen, C., \& Chen, F. (2014). Consumer financial capability and financial satisfaction. Social Indicators Research, 118(1), 415-432. doi: 10.1007/s11205-013-0414-8

Joo, S., \& Grable, J. (2004). An Exploratory Framework of the Determinants of Financial Satisfaction. Journal of Family and Economic Issues, 25(1), 25-50.

Kempson, E., Perotti, V., \& Scott, K. (2013). Measuring financial capability: a new instrument and results from low- and middle-income countries. Washington, DC: World Bank.

Loke, V., Choi, L., \& Libby, M. (2015). Increasing Youth Financial Capability: An Evaluation of the MyPath Savings Initiative. Journal of Consumer Affairs, 49(1), 97-126. doi: 10.1111/joca.12066

Lusardi, A., \& Mitchell, O. S. (2011). Financial Literacy and Planning: Implications for Retirement Well-being. In O. S. Mitchell \& A. Lusardi (Eds.), Financial Literacy: Implications for Retirement Security and the Financial Marketplace. Oxford: Oxford University Press. doi: 10.1093/acprof:oso/9780199696819.003.0002

Lusardi, A., \& Mitchell, O. S. (2014). The Economic Importance of Financial Literacy: Theory and Evidence. Journal of Economic Literature, 52(1), 5-44. doi: 10.1257/jel.52.1.5

Lusardi, A., Mitchell, O. S., \& Curto, V. (2010). Financial Literacy among the Young. Journal of Consumer Affairs, 44(2), 358-380. doi: 10.1111/j.1745-6606.2010.01173.x

Lusardi, A., \& Mitchelli, O. S. (2007). Financial Literacy and Retirement Preparedness: Evidence and Implications for Financial Education. Business Economics, 42(1), 35-44. doi: $10.2145 / 20070104$

Luukkanen, L., \& Uusitalo, O. (2019). Toward Financial Capability: Empowering the Young. Journal of Consumer Affairs, 53(2), 263-295. doi: 10.1111/joca.12186

Meyers, L. S., Gamst, G. C., \& Guarion, A. J. (2013). Performing data analysis using IBM SPSS. New Jersey: Wiley.

Mudzingiri, C., Muteba Mwamba, J. W., \& Keyser, J. N. (2018). Financial behavior, confidence, risk preferences and financial literacy of university students. Cogent Economics and Finance, 6(1), 1-25. doi: 10.1080/23322039.2018.1512366

Pallant, J. (2016). SPSS survival manual: a step by step guide to data analysis using IBM SPSS. New York: McGraw-Hill.

Potocki, T., \& Cierpiał-Wolan, M. (2019). Factors shaping the financial capability of lowincome consumers from rural regions of Poland. International Journal of Consumer Studies, 43(2), 187-198. doi: 10.1111/ijcs.12498 
Potrich, A. C. G., Vieira, K. M., \& Kirch, G. (2015). Determinants of Financial Literacy: Analysis of the Influence of Socioeconomic and Demographic Variables. Revista Contabilidade \& Finanças, 26(69), 362-377. doi: 10.1590/1808-057x201501040

Potrich, A. C. G., Vieira, K. M., \& Kirch, G. (2018). How well do women do when it comes to financial literacy? Proposition of an indicator and analysis of gender differences. Journal of Behavioral and Experimental Finance, 17, 28-41. doi: 10.1016/J.JBEF.2017.12.005

Potrich, A. C. G., Vieira, K. M., \& Mendes-Da-Silva, W. (2016). Development of a financial literacy model for university students. Management Research Review, 39(3), 356-376. doi: 10.1108/MRR-06-2014-0143

Rai, K., Dua, S., \& Yadav, M. (2019). Association of Financial Attitude, Financial Behaviour and Financial Knowledge Towards Financial Literacy: A Structural Equation Modeling Approach. FIIB Business Review, 8(1), 51-60. doi: 10.1177/2319714519826651

Remund, D. L. (2010). Financial Literacy Explicated: The Case for a Clearer Definition in an Increasingly Complex Economy. Journal of Consumer Affairs, 44(2), 276-295. doi: 10.1111/j.1745-6606.2010.01169.x

Robb, C. A., \& Woodyard, A. S. (2011). Financial Knowledge and Best Practice Behavior. Journal of Financial Counseling and Planning, 22(1), 60-70. Retrieved from https://ssrn.com/abstract $=2061308$

Rothwell, D. W., Khan, M. N., \& Cherney, K. (2016). Building Financial Knowledge Is Not Enough: Financial Self-Efficacy as a Mediator in the Financial Capability of LowIncome Families. Journal of Community Practice, 24(4), 368-388. doi: 10.1080/10705422.2016.1233162

Serido, J., Shim, S., \& Tang, C. (2013). A developmental model of financial capability: A framework for promoting a successful transition to adulthood. International Journal of Behavioral Development, 37(4), 287-297. doi: 10.1177/0165025413479476

Sherraden, M. S., \& Ansong, D. (2016). Financial Literacy to Financial Capability: Building Financial Stability and Security. In C. Aprea, E. Wuttke, K. Breuer, N. K. Koh, P. Davies, B. Greimel-Fuhrmann, \& J. S. Lopus (Eds.), International Handbook of Financial Literacy. Singapore: Springer. doi: 10.1007/978-981-10-0360-8

Shih, T. Y., \& Ke, S. C. (2014). Determinates of financial behavior: Insights into consumer money attitudes and financial literacy. Service Business, 8(2), 217-238. doi: 10.1007/s11628-013-0194-X

Shim, S., Serido, J., Bosch, L., \& Tang, C. (2013). Financial identity-processing styles among young adults: A longitudinal study of socialization factors and consequences for financial capabilities. Journal of Consumer Affairs, 47(1), 128-152. doi: 10.1111/joca.12002

Taylor, M. (2009). The impact of life events on financial capability: Evidence from the BHPS. Financial Services Authority Consumer Research, No. 79. Retrieved from https://www.fca.org.uk/publication/research/fsa-crpr79.pdf

Vieira, K. M., Caroline, A., \& Potrich, G. (2019). A Financial Literacy Model for University Students. In W. Mendes-Da-Silva (Ed.), Individual Behaviors and Technologies for Financial Innovations. Austin, Texas: Springer. doi: 10.1007/978-3-319-91911-9_4

Vlaev, I., \& Elliott, A. (2017). Defining and influencing financial capability. In R. Ranyard (Ed.), Economic Psychology. Chichester: Wiley. doi: 10.1002/9781118926352.ch12 
Woodyard, A., \& Robb, C. (2012). Financial Knowledge and the Gender Gap. Journal of Financial Therapy, 3(1), 1-16. doi: 10.4148/jft.v3i1.1453

Xiao, J. J., Chen, C., \& Chen, F. (2014). Consumer Financial Capability and Financial Satisfaction. Social Indicators Research, 118(1), 415-432. doi: 10.1007/s11205-0130414-8

Xiao, J. J., Chen, C., \& Sun, L. (2015). Age differences in consumer financial capability. International Journal of Consumer Studies, 39, 387-395. doi: 10.1111/ijcs.12205

Xiao, J. J., \& O’Neill, B. (2016). Consumer financial education and financial capability. International Journal of Consumer Studies, 40(6), 712-721. doi: 10.1111/ijcs.12285

\section{Contact information}

\section{Gentjan Çera}

Tomas Bata University in Zlín, Faculty of Management and Economics

Mostní 5139, 76001, Zlín, Czech Republic

E-mail: cera@utb.cz

ORCID: 0000-0002-9324-181X

\section{Bekim Poleshi, M.Sc.}

Epoka University, Faculty of Economics and Administrative Sciences

Rr. Tiranë-Rinas, Km. 12, 1032 Vorë, Tirana, Albania

E-mail: bekimpoleshi7@gmail.com

ORCID: 0000-0002-4330-7008

\section{Khurram Ajaz Khan}

Tomas Bata University in Zlín, Faculty of Management and Economics Mostní 5139, 76001, Zlín, Czech Republic

E-mail:khan@utb.cz

ORCID: 0000-0001-5728-8955

\section{Arjan Shumeli, Associated professor}

Agricultural University of Tirana, Faculty of Economics and Agribusiness

"Pajsi Vodica", 1029 Tirana, Albania

E-mail: ashumeli@ubt.edu.al

ORCID: 0000-0002-3737-8176

\section{Oksana Kojku, M.Sc.}

Agricultural University of Tirana, Faculty of Economics and Agribusiness "Pajsi Vodica", 1029 Tirana, Albania

E-mail: oksana.kojku@gmail.com

ORCID: 0000-0002-5387-7872

doi: $10.7441 /$ dokbat.2019.018 